\title{
Deterioration of the fuel injection parameters as a result of Common Rail injectors deposit formation
}

\author{
Zbigniew Stępień ${ }^{1, *}$ \\ ${ }^{1}$ Oil and Gas Institute - National Research Institute, 31-503 Cracow, ul. Lubicz 25A, Poland
}

\begin{abstract}
The article describes external and internal Common Rail injectors deposits formed in dynamometer engine simulation tests. It discussed not only the key reasons and factors influencing injector deposit formation but also the resulting way of fuel preparation and engine test approaches. The effects of external coking deposit as well as internal deposits two most common form types that is carboxylic soaps and organic amides on deterioration of the fuel injection parameters were assessed. The assessments covered both deposits impacts on quantitative and qualitative changes of the injectors diagnostic parameters and as a result on deterioration of the injector performance. Finally the comparisons between characteristic of dosage of one fuel injector before test and characteristics few injectors after engine tests of simulated deposit formation were made.
\end{abstract}

\section{Introduction}

Problems arising from build-up of different types of damaging deposits in diesel fuel injectors is well known since many years now and was extensively described in many scientific publications including [1-3]. In the 1980s the build-up of external injector deposits on the pintle of a fuel injector has caused a significant concern of fuel systems producers and introduction of DCA (Deposit Control Additives) to reduce injector fouling occurred [4]. Continuing since 1997 development of HPCR (High Pressure Common Rail) systems which design features are more conductive or susceptible to deposit formation, especially IDID (Internal Diesel Injector Deposits), such as severe high temperature along with high pressure operating conditions as well as precision engineering to operate highly controlled multiple injection strategies [57]. This may rise problems in the field due to deposits that have formed on their critical moving parts, such as the needle and control valve and manifested themselves as injector sticking, rough idling, power loss, issues with drivability, high emissions and many more [8-10]. The current industry focus is on internal injector needle deposits. These IDID have been categorized in four main types: higher carboxylate deposit, amide deposit, ester lower carboxylate - cold flow improver deposit and ester lower carboxylate - FAME deposit [10-15]. The mechanism of IDID deposit formation is different from that of external deposits on the injection nozzles, because internal deposits are not exposed to exhaust gas generated during combustion and surface evaporation of fuel. IDID are formed as a result of deteriorated fuel which becomes deposit adheres to the material surface by physical binding or deteriorated fuel which adheres to the material surface by chemical binding $[2,16]$. It was concluded that in case of diesel engines with indirect fuel injection the amount and rate of coke formation were widely influenced by the type of injector used, in case of direct fuel injection it is the fuel that plays the key role in formation of the subject coke deposits. Wider use of low sulfur diesel fuels and fuel additives gave way to fuels containing acid components. For example, to a different extent, unsaturated fatty acids are commonly used as lubricant additives. These acids easily react with metallic ions of the fuel contaminants forming carboxylic salts, that, similarly to low molecular mass polar compounds, much worse dissolve in low sulfur diesel fuels of low content of aromatic hydrocarbons compared to old high sulfur content fuels $[1-4,16,17]$. A growing share of FAME (Fatty Acid Methyl Esters) characterized by low stability in the diesel fuels accelerates the process of fuel oxidation and degradation. FAME are a source of weak acids and lead to an increase in the fuel contamination (sodium compounds) - a component of typical catalysts used in the reaction of transestrification [1-4, 16-19]. Hence, due to their low stability, the resistance to oxidation is one of the most important properties of diesel fuels containing FAME. Consequently, in the market today there are a variety of fuel qualities. At the same time DCA additives used in fuels are generally considered to be the most effective way to counteract injector deposit formation. However, currently, widely applied detergents preventing external coke deposits on the injectors are based on PIBSI (Polyisobutylene Succinimide) and in combination with the previously described factors may facilitate the formation of IDID [1-4]. Therefore, the development and manufacture of these type additives is critical to their performance in the field in terms of functioning to control both external and internal deposits but also from a nocharm standpoint $[4,20,21]$.

* Corresponding author stepien@inig.pl 
This paper reports results generated to develop further knowledge relating to the engine test investigations into external and internal common rail injector deposit formation. The main research problems concerned the possibilities of reproducing different type of injector deposits in engine bench tests that simulated conditions of real operation. The main target of the research was to investigate the problem of injector deposit formation and to try to identify the source of the problem. It was important to study the effects of diesel fuel properties on the common rail injector functioning because the fuel could deteriorate inside an injector at such severe conditions and build-up of damaging deposits. As a criterion for assessing the effects of external and internal deposits reproduced during engine simulation tests were used diagnostic parameters of injector functioning and their characteristics of fuel injection. In addition, visual assessments of the deposits were performed.

\section{Methodology}

\subsection{Reproduction engine test of injector deposit}

The engine simulation tests of injector deposits reproduction were performed on a multi-purpose test stand equipped with a modern, widely used HSDI (High Speed Direct Injection) FORD 2.0i 16V Duratorq TDCi diesel engine coupled with an Alpha 160 AF eddy current brake from AVL, with a control module allowing the programming of the engine operation parameters (rpm, load, phase time and ramp time between phases). The basic technical parameters of the FORD $2.0 \mathrm{i} 16 \mathrm{~V}$ Duratorq TDCi are given in Table 1.

Table 1. Selected technical parameters of the FORD 2.0i 16V Duratorq TDCi engine.

\begin{tabular}{|c|c|}
\hline Engine type & four-stroke, compression ignition \\
\hline Fuel injection type & $\begin{array}{c}\text { direct fuel injection, common rail } \\
\text { (Delphi) electronically controlled, } \\
\text { cooperating with the Levanta } \\
\text { engine control system }\end{array}$ \\
\hline Cylinders arrangement & in-line, vertical \\
\hline No. of cylinders & 4 \\
\hline Injection sequence & $1-3-4-2$ \\
\hline Type of timing gear & $\mathrm{DOHC} / 4 \mathrm{VPC}$ \\
\hline Cylinder diameter & $86.0 \mathrm{~mm}$ \\
\hline Piston stroke & $86.0 \mathrm{~mm}$ \\
\hline Displacement & $1998 \mathrm{~cm}^{3}$ \\
\hline Maximum power & $130 \mathrm{KM}(96 \mathrm{~kW})$ at $3800 \mathrm{rpm}$ \\
\hline Max. torque & $330 \mathrm{Nm}$ at $1800 \mathrm{rpm}$ \\
\hline Max. speed & $4800 \mathrm{rpm}$ \\
\hline Idle speed & $750 \pm 20 \mathrm{rpm}$ \\
\hline Compression ratio & 18.2 \\
\hline Filling & $\begin{array}{l}\text { turbocharged with intercooler and } \\
\text { "overboost" function }\end{array}$ \\
\hline Valve clearance & hydraulic adjustment \\
\hline $\begin{array}{l}\text { Capacity of lubrication } \\
\text { system with filter }\end{array}$ & $6.0 \mathrm{dm}^{3}$ \\
\hline $\begin{array}{l}\text { Complies with emission } \\
\text { standard }\end{array}$ & Euro IV \\
\hline
\end{tabular}

The engine tests were performed in a 4-phase, repeatable cycle which reflected the average engine operating conditions in a low-intensity city traffic. The parameters of the 4-phase cycle are given in Table 2.

Table 2. Parameters of the 4-phase engine cycle.

\begin{tabular}{|c|c|c|c|}
\hline Phase & $\begin{array}{c}\text { Time } \\
{[\mathrm{s}]}\end{array}$ & $\begin{array}{c}\text { Engine speed } \\
{[\mathrm{rpm}]}\end{array}$ & $\begin{array}{c}\text { Engine load } \\
{[\mathrm{Nm}]}\end{array}$ \\
\hline 1 & 30 & 1000 & $\sim 0$ \\
\hline 2 & 150 & 1800 & 100 \\
\hline 3 & 60 & 3000 & 70 \\
\hline 4 & 60 & 1500 & 50 \\
\hline
\end{tabular}

The test duration was 100 hours of actual engine operation in 8-hour periods which comprised repetitions of the 4-phase cycle (Table 2) and were separated by 16hour soak period during which the formed deposits stabilized.

When the test was complete, the injectors were removed from the engine and two of them were sent for full, professional assessment of diagnostics parameters and the other two were left to take photographs of the internal deposits. The necessity for such procedure resulted from the fact that the deposits may be subject to mechanical and chemical damage/changes during the diagnostics and in the final stage they are removed in order to evaluate the parameters and the adjustment possibilities of the "cleaned" injectors. On the other hand, before the diagnostics the injectors must not be dismantled (e.g. for photographing and evaluation of deposits) as this would affect (distort) the diagnostic parameters after the test.

The injector evaluation after the test comprised both the external coke deposits injectors and the IDID. In case of the IDID, the obligatory evaluation was performed on the injector needle and solenoid valve control piston as components with critical impact on the correct injector operation, and in addition most often subject to damage.

The measurements and evaluations of selected diagnostic parameters were performed on the Zapp CRU.2 $\mathrm{i}$ testing device. The evaluations of each diagnostic parameters are an average value from three measurements. Characteristics injectors fuel delivery were taken - off on the Hartridge CRi-PC test bench.

\subsection{Tests Fuels Preparation}

In order to accelerate the formation of injector deposits (especially the IDID), the engine was running on the naturally aged, commercially available diesel fuel containing $4.78 \%(\mathrm{v} / \mathrm{v})$ of FAME - Table 3 . Furthermore, an additional admixture of naturally aged FAME - Table 3, was used in some tests fuels.

The results of the to date analysis of sodium soaps (or sodium carboxylate) type IDIDs identified alkenyl succinic acids, like dodecenyl succinic acid (DDSA) and hexadecenyl succinic acid (HDSA), which are commonly used as pipeline corrosion inhibitors in the petroleum industry [22-24]. It was also considered that if higher molecular weight carboxylates and sodium are contained in diesel fuel simultaneously, carboxylate salt 
deposits are build-up on metal surfaces at temperatures of 130 degress $\mathrm{C}$ or higher [8]. Moreover, sodium ions are captured by fatty acids, which are a by-product of FAME blended into diesel fuel. When sodium ions and fatty acids meet, sodium soaps form [25].

Sources of amide deposits as well mechanism for amide lacquer formation is less recognized but it is most likely derived from polyisobutylene succinimides (PIBSI) which are added to diesel fuel as a major component of DCA. Two hypothesis are widely known for the formation of amide type IDID. One hypothesis assumes that deposits are formed through the reaction of PIBSI with fatty carboxylic acid to form an amide $[8,17$, 22]. The other assumes that it is the low molecular weight portion of the PIBSI that is responsible for the deposit formation as it is only sparingly soluble in the diesel fuel and thus deposits on the surfaces of the inner injector parts [20, 22].

For this reason, added to the test fuel as 1-litre premixes were mixtures of chemical compounds which according to the available results of tests performed at various laboratories have the greatest impact on the formation of various IDID [9, 18, 20, 26-31]. The said chemical compounds comprised the ingredients present in detergent and lubrication additives, corrosion inhibitors, additives increasing the cetane number and the contaminants which make their way into to the fuel. As a result, three fuels described below were prepared for the simulation engine tests.

In test No. 1, the propensity for the formation of external and internal deposits was tested on the aged, commercially available diesel fuel (physical and chemical properties are given in Table 3) with addition of $0.5 \mathrm{ppm} \mathrm{Na}^{+}+70 \mathrm{ppm}$ dodecenyl succinic acid (DDSA). This aimed at accelerating the formation of carboxylate deposits, in this case sodium soaps by adding " $\mathrm{Na}$ " as metallic contaminant often appears in diesel fuels and dodecenyl succinic acid (DDSA) which is ingredient of corrosion inhibitors also occurs in diesel fuels.

Table 3. Selected physical and chemical properties of fuels used during engine tests.

\begin{tabular}{|c|c|c|c|c|}
\hline Tested parameter & Test method & Unit & Diesel fuel & B100 \\
\hline Oxidation stability & PN-EN 15751:2014 & $\mathrm{h}$ & 19.8 & 4.9 \\
\hline Resistance to oxidation & PN-EN ISO 12205:2011+Ap1:2011 & $\mathrm{g} / \mathrm{m}^{3}$ & 5 & 32 \\
\hline Oxidation stability & ASTM D 7545-14 & minute & 39 & 23 \\
\hline $\begin{array}{l}\text { Corrosion properties to steel: } \\
\text { - temp. } 38^{\circ} \mathrm{C} \text {, test time } 5 \mathrm{~h} \\
\text {-temp. } 50^{\circ} \mathrm{C} \text {, test time } 3 \mathrm{~h}\end{array}$ & $\begin{array}{l}\text { ASTM D } 665-14 \\
\text { Procedure A (distilled water) }\end{array}$ & - & $\begin{array}{l}\text { no } \\
-\end{array}$ & $\begin{array}{c}- \\
\text { no }\end{array}$ \\
\hline Contaminants & $\begin{array}{l}\text { PN-EN 12662:2014 } \\
\text { PN-EN 12662:2009 }\end{array}$ & $\mathrm{mg} / \mathrm{kg}$ & $\begin{array}{c}6.0 \\
-\end{array}$ & $\begin{array}{c}- \\
182.5\end{array}$ \\
\hline Kinematic viscosity at $40^{\circ} \mathrm{C}$ & PN-EN ISO 3104:2004 & $\mathrm{mm}^{2} / \mathrm{s}$ & 3.113 & 4.540 \\
\hline $\begin{array}{l}\text { Distribution of contaminants: } \\
\cdot 4,6 \text { and } 14 \mu \mathrm{m} \\
\cdot 2 \text { and } 5 \mu \mathrm{m}\end{array}$ & $\begin{array}{l}\text { ISO 11500:2008 and } \\
\text { PN-ISO 4406:2005 }\end{array}$ & - & $\begin{array}{c}18 / 16 / 14 \\
18 / 16 \\
\end{array}$ & $\begin{array}{c}23 / 23 / 23 \\
23 / 23 \\
\end{array}$ \\
\hline $\begin{array}{l}\text { Fractional composition: } \\
\text { - up to temp. } 250^{\circ} \mathrm{C} \text { distils } \\
\text { - up to temp. } 350^{\circ} \mathrm{C} \text { distils } \\
\text { - } 95 \%(\mathrm{v} / \mathrm{v}) \text { distils up to temp. }\end{array}$ & PN-EN ISO 3405:2012 & $\begin{array}{l}\%(\mathrm{v} / \mathrm{v}) \\
\%(\mathrm{v} / \mathrm{v}) \\
{ }^{\circ} \mathrm{C}\end{array}$ & $\begin{array}{r}29.6 \\
92.6 \\
358.8\end{array}$ & - \\
\hline Density at $15^{\circ} \mathrm{C}$ & PN-EN ISO 12185:2002 & $\mathrm{kg} / \mathrm{m}^{3}$ & 838.8 & - \\
\hline Sulfur content & PN-EN ISO 20846:2012 & $\mathrm{mg} / \mathrm{kg}$ & 7.7 & - \\
\hline Water content & PN-EN ISO 12937:2005 & $\mathrm{mg} / \mathrm{kg}$ & 65 & - \\
\hline Flash point & PN-EN ISO 2719:2007 & ${ }^{\circ} \mathrm{C}$ & 69 & - \\
\hline Cetane number & PN-EN 5165:2014 & ${ }^{-}$ & 52.8 & - \\
\hline Cetane index & $\begin{array}{l}\text { PN-EN ISO 4264:2010 + A1:2013- } \\
07\end{array}$ & - & 54.1 & - \\
\hline Cold filter plugging point (CFPP) & PN-EN 116:2015 & ${ }^{\circ} \mathrm{C}$ & -6 & - \\
\hline Carbon residue from $10 \%$ distillation residue & PN-EN ISO 10370:2014 & $\%(\mathrm{~m} / \mathrm{m})$ & 0.048 & - \\
\hline Ash residue & PN-EN ISO 6245:2008 & $\%(\mathrm{~m} / \mathrm{m})$ & $<0.001$ & - \\
\hline
\end{tabular}

In test No. 2, the propensity for the formation of external and internal deposits was tested on the aged, commercially available diesel fuel (physical and chemical properties are given in Table 3) with addition of $120 \mathrm{ppm}$ of PIBSI (Polyisobutylene Succinimide) + $100 \mathrm{ppm}$ of hydrogenated dimer of oleic acid $+1 \mathrm{ppm}$ of formic acid. This aimed at accelerating the formation of amide deposits by adding PIBSI on which the detergent additives to diesel fuel are based and by adding acidic substances which are ingredients of lubrication additives.

In test No. 3 , similarly to test No. 1 , the propensity for the formation of external and internal deposits was tested on the aged, commercially available diesel fuel
(Table 3 ) in which the content of biocomponents $(4.78 \%$ (v/v) FAME) was increased to $10 \%(\mathrm{v} / \mathrm{v})$ by adding aged $\mathrm{B} 100$ (properties given in Table 2). Moreover, $500 \mathrm{ppm}$ of 2 ethyl-hexyl nitrate $(2-\mathrm{EHN})+120 \mathrm{ppm}$ of PIBSI (small molecular mass) were added to the fuel. This aimed at accelerating the formation of amide (polymertype) deposits by adding PIBSI on which the detergent additives to diesel fuel are based and the formation of ester deposits from aged FAME in tandem with 2 ethylhexyl nitrate (2-EHN) added to increase the cetane number. 


\section{Results}

Figure 1 presents the tips of two examples of injectors after test No. 1.
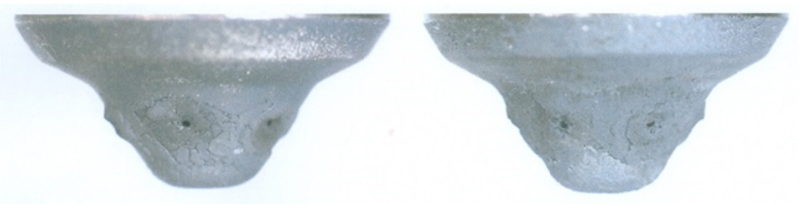

Fig. 1. Photographs of injector tips after engine test No. 1.

On the injector tips were formed quite thick layers unevenly distributed, mat, dry, light grey deposits. The deposits are thicker around the fuel outlet holes. For a few outlet holes their exit cross-sections are limited by the deposits. The cracks and peeling of deposits is present in some areas - Fig. 1. The size and distribution of deposits on the surfaces of evaluated injector tips is similar. Figure 2 shows injector needle of one of injectors after test No. 1.
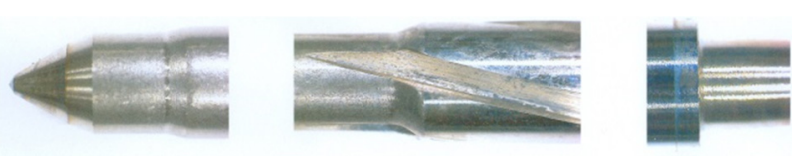

Fig. 2. Deposit formed at the injector needle after test No. 1.

A light grey coloured, typical carboxylate deposit, was observed the whole surface of the injector needles. Particularly intensive deposits were found on the cylindrical part of needles directly above the conical part - Fig. 2. A layer of uneven, light grey deposit with traces of wipping was also observed on sliding, cylindrical surfaces of the needles. Such deposits may result sticking of the inner injector components or delay of the injector response on the control signal. This can lead in some injectors not injecting at all low rail pressures, thus causing difficulties in restarting and poor running at idle. A similar type and colour IDIDs were observed at the plungers and heads of pistons of the fuel flow control valves - Fig. 3 .
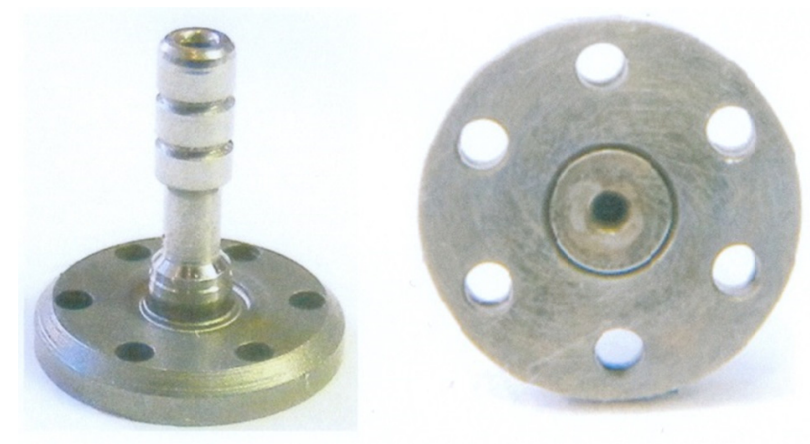

Fig. 3. Deposit formed at the plunger and head of piston of the fuel flow control valve after test No. 1 .

The next part of the evaluation comprised a measurement of selected diagnostic parameters of two injectors after test No. 1. The results of the all injector assessments from three carried out tests are summarised in Table 4. The measurements and assessments of these selected diagnostic parameters were performed on the Zapp CRU.2i testing device.

Table 4. Assessment results of selected injector diagnostic parametters.

\begin{tabular}{|c|c|c|c|c|c|}
\hline \multicolumn{2}{|c|}{$\begin{array}{l}\text { Assessments } \\
\text { after test No. } 1\end{array}$} & \multicolumn{2}{|c|}{$\begin{array}{l}\text { Assessments } \\
\text { after test No. } 2\end{array}$} & \multicolumn{2}{|c|}{$\begin{array}{c}\text { Assessments } \\
\text { after test No. } 3\end{array}$} \\
\hline $\begin{array}{l}\text { Injector } \\
\text { No. } 1\end{array}$ & $\begin{array}{l}\text { Injector } \\
\text { No. } 2 \\
\end{array}$ & $\begin{array}{l}\text { Injector } \\
\text { No. } 1 \\
\end{array}$ & $\begin{array}{l}\text { Injector } \\
\text { No. } 2 \\
\end{array}$ & $\begin{array}{l}\text { Injector } \\
\text { No. } 1 \\
\end{array}$ & $\begin{array}{l}\text { Injector } \\
\text { No. } 2 \\
\end{array}$ \\
\hline \multicolumn{6}{|c|}{$\begin{array}{c}\text { Fuel dose size assessment }\left[\mathrm{mm}^{3} / \text { stroke }\right] \text { at injection } \\
\text { frequency, pressure, and injector opening time } \\
\text { (400 injections/minute, } 160 \mathrm{MPa}, 400 \mu \mathrm{s} \text {, respectively) }\end{array}$} \\
\hline PASS & FAIL & FAIL & FAIL & FAIL & FAIL \\
\hline \multicolumn{6}{|c|}{$\begin{array}{l}\text { Fuel dose size assessment }[\mathrm{mm} 3 / \text { stroke] at injection } \\
\text { frequency, pressure, and injector opening time } \\
\text { (400 injections/minute, } 120 \mathrm{MPa}, 412 \mu \mathrm{s} \text {, respectively) }\end{array}$} \\
\hline PASS & PASS & PASS & PASS & PASS & FAIL \\
\hline \multicolumn{6}{|c|}{$\begin{array}{l}\text { Fuel dose size assessment }[\mathrm{mm} 3 / \text { stroke }] \text { at injection } \\
\text { frequency, pressure, and injector opening time } \\
\text { (400 injections/minute, } 80 \mathrm{MPa}, 450 \mu \mathrm{s} \text {, respectively) }\end{array}$} \\
\hline PASS & PASS & PASS & PASS & PASS & FAIL \\
\hline \multicolumn{6}{|c|}{$\begin{array}{c}\text { Fuel dose size assessment [mm3/stroke] at injection } \\
\text { frequency, pressure, and injector opening time } \\
\text { (1500 injections/minute, } 23 \mathrm{MPa}, 685 \mu \mathrm{s} \text {, respectively) }\end{array}$} \\
\hline PASS & PASS & PASS & PASS & PASS & PASS \\
\hline \multicolumn{6}{|c|}{$\begin{array}{l}\text { Injector response time assessment }[\mu \mathrm{s}] \text { to the electric } \\
\text { control pulse at one specific injection frequency, pressure, } \\
\text { and injector opening time (1000 injections/minute, } 80 \mathrm{MPa} \text {, } \\
450 \mu \mathrm{s} \text {, respectively) }\end{array}$} \\
\hline PASS & FAIL & FAIL & PASS & PASS & PASS \\
\hline
\end{tabular}

The injectors evaluations after test No. 1, presented in Table 4, indicate that the injector No. 2 has failed the requirements for the limit values of dosed fuel at the injection pressure of $160 \mathrm{MPa}$ and the injector opening time of $400 \mu$ s as well as for injector response time. As a result, from the point of view of operational parameters, the injector was not fit for further use without maintenance-repair operations comprising washing, adjustment and possibly replacement of some internal parts. The most probable reasion of such deterioration of the injector diagnostic parameters were internal deposits formed on the working part of the needle which slides on the injector body, and on the plunger of the fuel flow control piston inside the injector. This changed the injector operation time as a result of a delayed or slowed down response of the needle to the electric control pulse, and even caused a possibility of the needle's hanging in the injector body. Injectors fuel delivery characteristics taken - off on the Hartridge CRi-PC test bench are presented in Fig. 4.

For both characteristics were observed delivery drift especially for low pulse width and delivery restriction in particular for maximum injection pressures (160 MPa). In the case of injector No. 2, the change in injection rate to IDID adhesion manifests itself in injection delayed as shown in Fig. 4. When the injection start is delayed, the fuel injection quantity decrease is observed. This observation are consistent with assessments selected diagnostic parameters and confirm that carboxylate deposits impact on change in injection quality that may 
have adverse effects on different injection volume quantities among cylinders. For comparison, Fig. 5 presents example of characteristics curves of the new fuel injector before test.

\section{Injector No. 1}

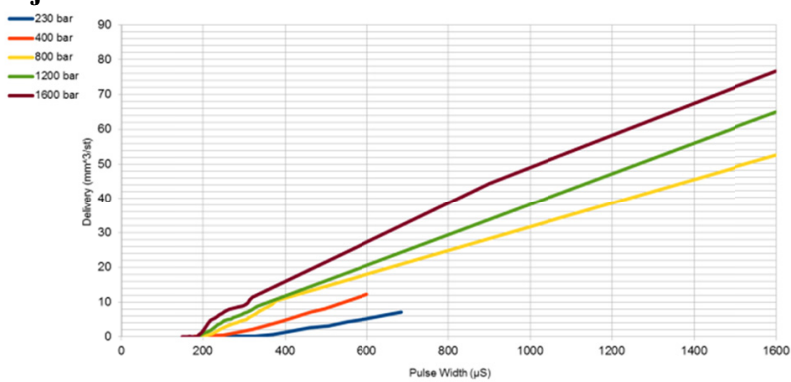

Injector No. 2

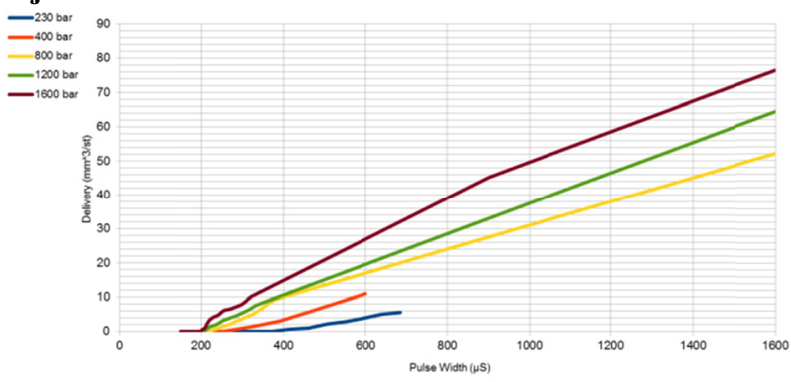

Fig. 4. Comparison of injector fuel delivery characteristics after engine test No. 1 .

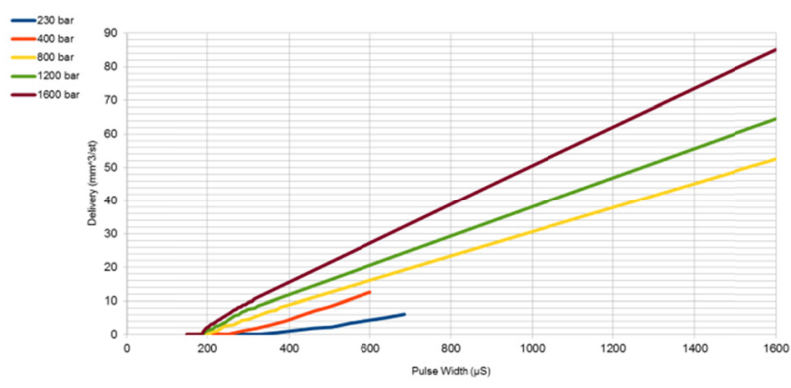

Fig. 5. Fuel delivery characteristics of the new fuel injector before test.

Figure 6 presents the tips of two examples of injectors after test No. 2 .

The injector tips have quite thick layers of uneven, mat, dry, dark greyish brown deposits. Deposits are much thicker around the fuel outlet holes. The cracks and peeling of deposits is present in some areas - Fig. 6 .

The size and distribution of deposits on the evaluated surfaces of both injectors is similar.
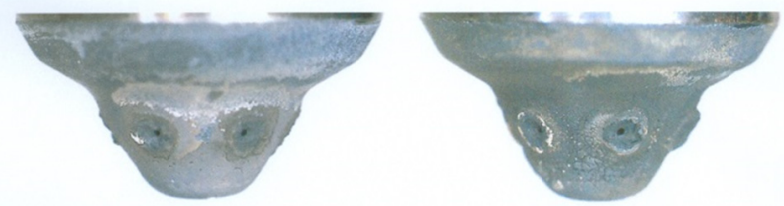

Fig. 6. Photographs of injector tips after engine test No. 2.
Figure 7 shows selected internal parts of one of injectors after test No. 2.

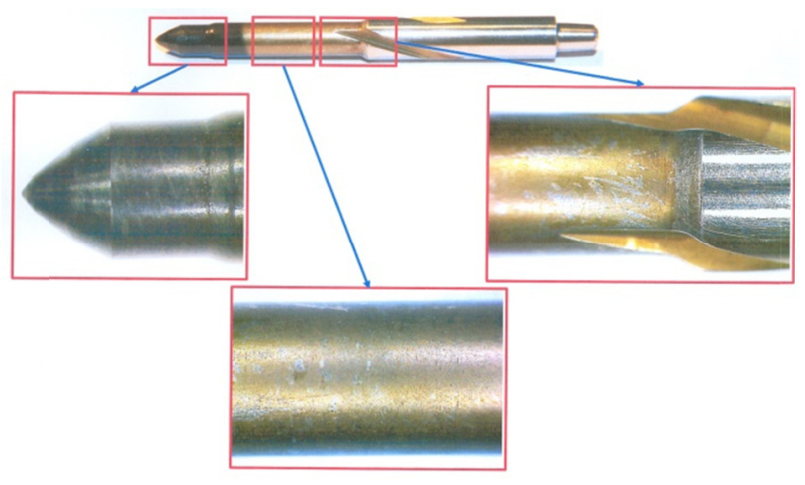

Fig. 7. Deposit formed at the injector needle after test No. 2.

Particularly intensive deposits, covering the surfaces in an irregular manner, were found on the conical ends of injector needles and on the cylindrical parts of needles directly above the conical part - Fig. 7. Colour as well appearance of these varnish-like deposits indicated the amide type deposits. More uniform amide deposits, although of varying thickness, covered the internal surfaces of grooves in the cylindrical guiding part of the needles. A very thin layer of light brown, sticky deposit can be observed around sliding part of the needles. A build-up of light brown deposits was also found on the plungers and heads of pistons of the fuel flow control valves - Fig. 8 .
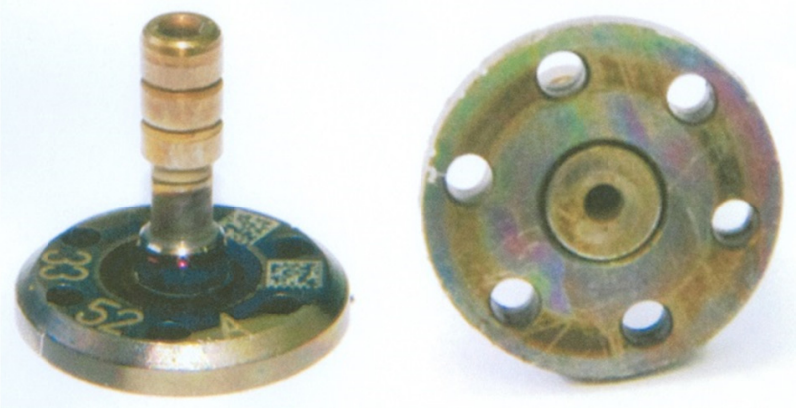

Fig. 8. Deposit formed at the plunger and head of piston of the fuel flow control valve after test No. 2.

These deposits especially those adhered into sliding surfaces of needles and control valves caused sticking or constrain operation of these injector components with critical impact on the correct injector operation.

Further evaluation comprised a measurement of selected diagnostic parameters of two injectors after test No. 2.

Assessment results of selected injector diagnostic parameters carried out using Zapp CRU.2i testing device showed that both injectors did not fulfil the requirements for fuel dose size at the injection pressure of $160 \mathrm{MPa}$ and the injector opening time of $400 \mu \mathrm{s}-$ Table 4 . As a consequence, from the point of view of operational parameters, the injectors were not fit for further use without maintenance-repair operations comprising washing, adjustment and possibly replacement of some 
internal parts. Apart from that, the injector No. 1 failed requirements regarding injector response time to the electric control pulse at specific injection frequency 1000 injections/minute, measured at pressure $80 \mathrm{MPa}$, and injector opening time $450 \mu$ s respectively - Table 4 .

The most probable reason of such deterioration of the injectors' diagnostic parameters were internal sticky, varnish-like deposits formed on sliding part of the injector needles co-acting with injector body, and on the plunger of the fuel flow control piston inside the injector. Observed after the test a few percent engine torque drop was induced by loss of fuel flow, induced likely by the external, nozzle coking deposits build-up around injectors fuel outlet holes and inside fuel channels as well as amide type IDID which changed the injector operation time as a result of a delayed or slowed down response of the needle to the electric control pulse. Injectors fuel delivery characteristics, after test No. 2, taken - off on the Hartridge CRi-PC test bench are presented in Fig. 9.

\section{Injector No. 1}

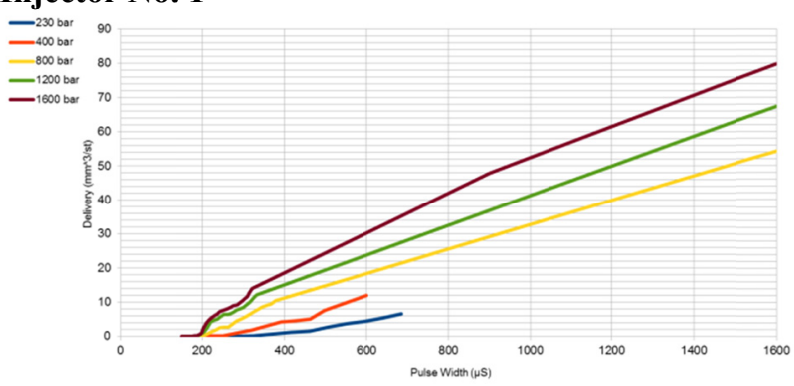

Injector No. 2

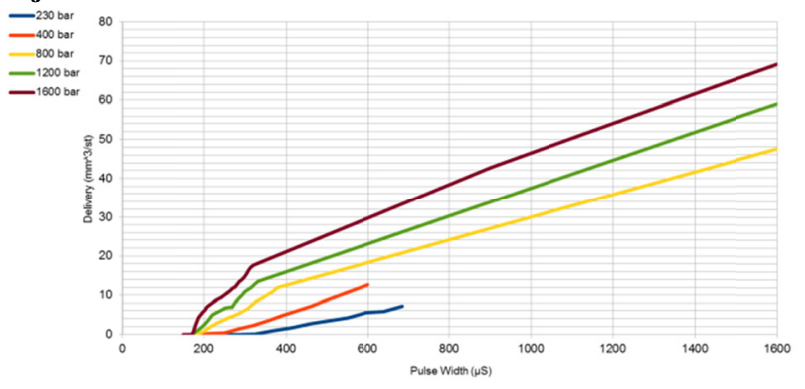

Fig. 9. Comparison of injector fuel delivery characteristics after engine test No. 2.

For both characteristics were observed delivery drift especially for low pulse width - Fig. 9. Delayed injection start is particularly apparent in the case of injector No. 1 what decrease fuel injection quantity especially for maximum injection pressures (160 MPa). The clear differences between both injector characteristics can be observed within pulse width between 200 up to $400 \mu \mathrm{s}$. This shows that IDID (in this case amide type) that collected on the nozzle needle guide, metering valves and other parts of the armature group of the fuel injectors could slow the response of the fuel injector or cause sticking of the moving internal parts, impairing the injection timing and quantity and the quality of fuel delivered per injection.
Figure 10 presents the tips of two examples of injectors after test No. 3 .

Mat, peeling deposits or varying thickness were formed on the injector tips. Deposits colour locally varies from dark brown to dark grey. The deposits created significant swellings around the fuel outlet holes - Fig. 10. Injector spray-hole deposits have been also observed. So located coking deposits may restrict flow area and therefore led to a flow rate reduction, resulting in loss of torque and power. The size and distribution of deposits on the evaluated surfaces of both injectors is similar.
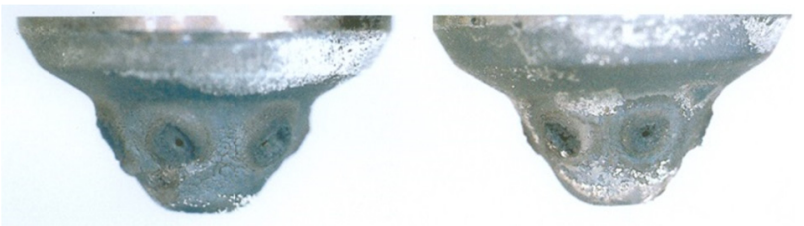

Fig. 10. Photographs of injector tips after engine test No. 3.

Figure 11 shows selected internal parts of injectors after test No. 3.

In the case of injector No. 2 after test No. 3, the needle was removed from its housing with difficulty and was clearly stuck. When both injectors from the test were dismantled, a combinations of amide lacquers as well carboxylate deposits has been observed. Intensive amide (polymer) deposits accompanied by ester deposits were formed on the injectors inside surfaces. On possibilities of the presence of biodiesel oxidation product indicates brownish lacquered appearance some deposits. A particularly large amount of deposits was found on conical ends of injector needles and on the cylindrical part of needles above the conical part. These deposits had an irregular shape and colour changing from yellow through orange, brown to dark brown. Fig. 11.

A layer of intensive polymer deposits were found on the cylindrical parts of the needle washed with fuel, and in grooves in the cylindrical guiding part of the needles, and also in grooves of plungers of the fuel flow control pistons- Fig. 11, 12. The sliding, cylindrical surfaces of needles and plungers feature areas where the deposits were mechanically rubbed during the injector operation - Fig. 11, 12. On the backside of the fuel flow control valve head were found slight traces of carboxylate deposits - Fig. 12.

The performance of the dismantled injectors including results of selected injector diagnostic parameters carried out in the same manner that is using Zapp CRU.2i testing device. Similarly to test No. 2, showed that both injectors did not fulfil the requirements for fuel dose size at the injection pressure of $160 \mathrm{MPa}$ and the injector opening time of $400 \mu$ s - Table 4 . Injector No. 2 did not fulfil the requirements also for fuel dose size at the injection pressure of $120 \mathrm{MPa}$ and the injector opening time of $412 \mu \mathrm{s}$, and also at the injection pressure of $80 \mathrm{MPa}$ and the injector opening time of 450 $\mu \mathrm{s}$ - Table 4. 


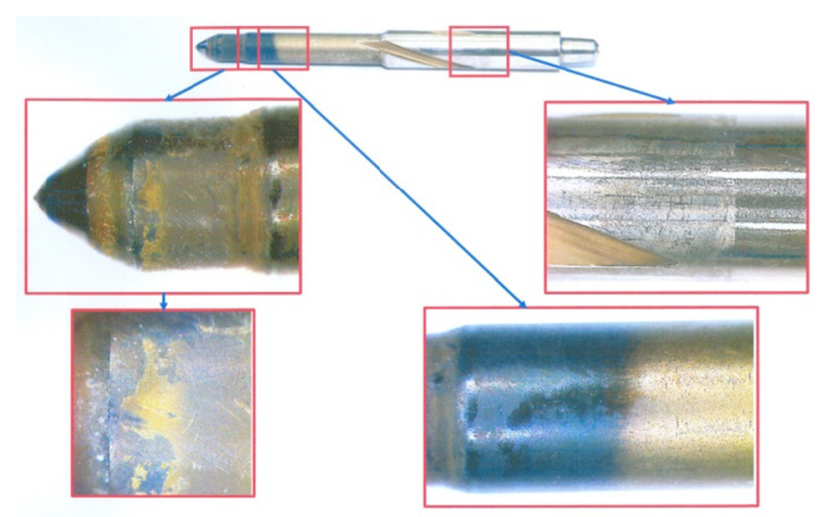

Fig. 11. Deposit formed at the injector needle after test No. 3 .
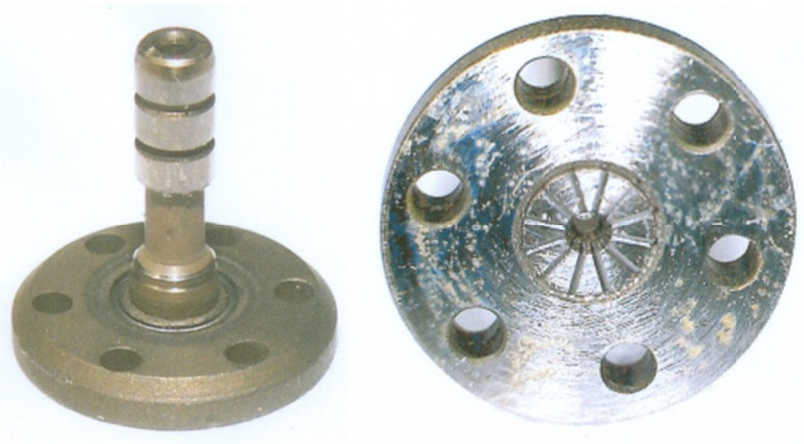

Fig. 12. Deposit formed at the plunger and head of piston of the fuel flow control valve after test No. 3 after Test No. 3 .

Similarly to test No. 2, the most probable reason of such deterioration of the injectors' diagnostic parameters were internal deposits formed on the working part of the needle which slides on the injector body, and on the plunger of the fuel flow control piston inside the injector. Observed after the test a few percent engine torque drop was due to a loss of fuel flow, induced likely by the external, external nozzle coking deposits around injectors fuel outlet holes and inside fuel channels as well as combinations of amide lacquers, carboxylate deposits and FAME decomposition deposits. These sticky IDID could have changed the injector operation time as a result of a delayed or slowed down response of the needle to the electric control pulse. Injectors fuel delivery characteristics, after test No. 3 , are presented in Fig. 13. The analysis of course of the injectors fuel delivery characteristics fully acknowledges the above observations and hypothesis. For both injectors is visible delayed injection start - Fig. 13. It also notes considerably decrease fuel injection quantity especially for maximum injection pressures (160 MPa), paying particular attention to sudden fall of the fuel delivery characteristic of the injector No. 2, for pulse widths above about $900 \mu \mathrm{s}$. Thus the observations are consistent with assessments selected diagnostic parameters and confirm that combinations of amide lacquers, carboxylate deposits and FAME decomposition deposits very significantly influences on change in injection quality that may have adverse effects on different injection volume quantities among cylinders.
Injector No. 1

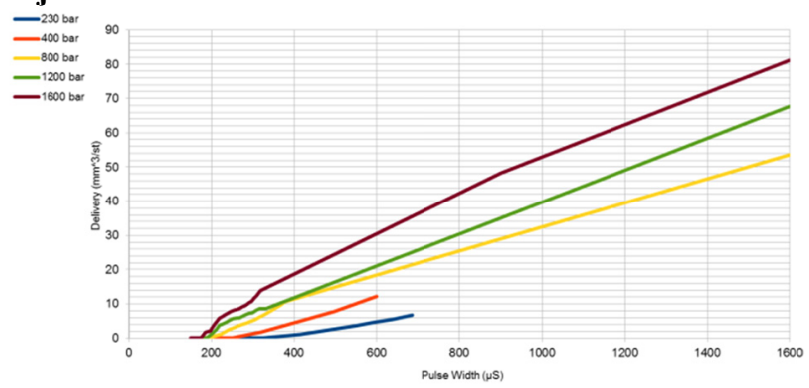

Injector No. 2

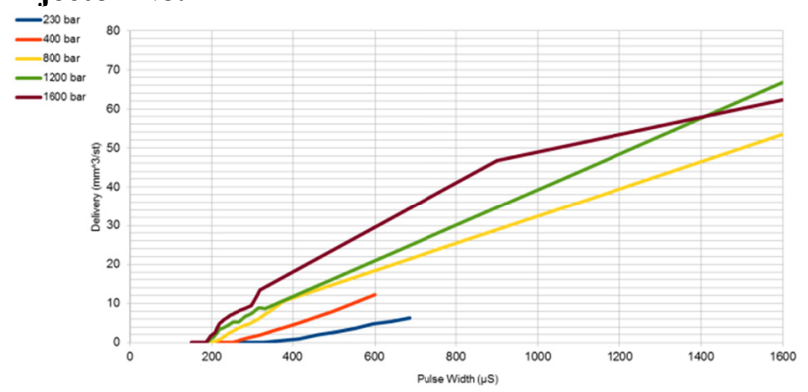

Fig. 13. Comparison of injector fuel delivery characteristics after engine test No. 3.

The analysis have also shown that when IDID forms, some injectors are impacted more than others. These more impacted injectors fail to deliver correct amount of fuel, and the injector better functioning inject more fuel to compensate for this.

\section{Conclusions}

An experimental investigations were carried out in order to better understand and evaluate impact of different type of injector deposits (both external and internal) on the common rail injector functioning. The research was preceded by reproducing different type of injector deposits in engine bench tests that simulated conditions of real operation. The most interesting aspect of the investigations are given below.

- Modern, advanced diesel fuel injection systems are susceptible and prone to the formation of a variety deposits including both external coking deposits and different IDID. These can occur in different locations, including among other things injector nozzle spray holes and channels, as well inside components of the injector body which threaten orderly functioning fuel injectors.

- The carried out engine tests prove the negative effect of some type both external and internal deposits on the operation and performance of the HPCR system.

- Changes to fuel composition and particularly fuel additives, possible trace metals contaminations and bio-components have in some cases increased potential of reactive species or provided new potential injector deposit precursors.

- External coking deposits in the nozzle orifices and inside fuel channels may have significant effect on engine power loss, which is due to reduction of fuel flow as deposits build up. 
- IDID that collected on the nozzle needle guide and inside the nozzle body, metering valves and other parts of the armature group of the fuel injectors could slow the response of the fuel injector or cause sticking of the moving internal parts, impairing the injection timing and quantity and the quality of fuel delivered per injection.

- The change in injection rate due to IDID adhesion manifests itself in injection start and end timing changes which results different fuel injection volume quantities among cylinders and relevant consequences.

\section{References}

1. Z. Stępień, Combustion Engines 156, 1 (2014)

2. Z. Stępień, Combustion Engines 163, 4 (2015)

3. Z. Stępień, Combustion Engines 165, 2 (2016)

4. G. Żak, L. Ziemiański, Z. Stępień, M. Wojtasik, Nafta-Gaz (2013)

5. I. Pielecha, K. Wislocki, P. Borowski, W. Cieslik, Journal of Thermal Analysis and Calorimetry 122, 473-485 (2015), DOI: 10.1007/s10973-015-4735-5

6. I. Pielecha, W. Cieslik, Journal of Thermal Analysis and Calorimetry 126, 815-827 (2016), DOI: 10.1007/s10973-016-5544-1

7. J. Nowakowski, K. Brzozowski, T. Knefel, Transport Means - Proceedings of the International Conference 333-336 (2015)

8. J. Ullmann, M. Gedulding, H. Stutzenberger, et al. SAE Technical Paper 2008-01-0926 (2008)

9. R. Quigeley, R. Barbour, E. Fahey, et al., TAE Fuels 7th Annual Colloquium (2009)

10. A. Tanaka, K. Yamada, T. Omori, et al., SAE Technical Paper 2013-01-2661 (2013)

11. K. Yamada, S. Bunne, T. Omori, 2015 Powertrains, Fuels and Lubricants Meeting TWS2 (2015)

12. W. Karpiuk, T. Borowczyk, M. Idzior, R. Smolec, 2016 International Conference on Sustainable Energy, Environment and Information Engineering 16-22 (2016)

13. J. Merkisz, P. Lijewski, P. Fuc, S. Weymann, Eksploatacja i Niezawodnosc - Maintenance and Reliability 15, 364-368 (2013)

14. W. Karpiuk, R. Smolec, M. Idzior, 2016 International Conference on Sustainable Energy, Environment and Information Engineering 37-43 (2016)

15. S. Schwab, J. Bennett, S. Dell, J. Galante-Fox et al. SAE Int. J. Fuels Lubricants 201, 865-878 (2010)

16. Internal diesel injector deposits, Coordinating Research Council, INC. CRC Project No. DP-0413a, CRC Report No. 665 (2013)

17. J. Ullmann, M. Gedulding H., Stutzenberger, et al., TAE Fuels 8th Annual Colloquium (2011)

18. R. Caprotti, N. Bhatti, G. Balfour, SAE Technical Paper 2010-01-2250 (2010)
19. P. Lacey, S. Gail, J Marc, et al. SAE Technical Paper 2012-01-1693 (2012)

20. J. Reid, J. Barker, SAE Technical Paper 2013-012682 (2013)

21. A. Suchecki, J. Nowakowski, T. Knefel, Transport Means - Proceedings of the International Conference 194-197 (2014)

22. R. Barbour, R. Quigley, A. Panesar, et al., 9th International Colloquium Fuels. Conventional and Future Energy for Automobiles (2013)

23. S. Schwab, J. Bennett, S. Dell, et al. SAE Technical Paper 2010-01-2242 (2010)

24. M. Almena, O. Esperilla, F. Manzanero, et al. SAE Technical Paper 2012-01-1689 (2012)

25. J. Ullmann, H. Stutzenberger, R. Bosch, 9th International Colloquium Fuels. Conventional and Future Energy for Automobiles (2013)

26. J. Baker, S. Cook, SAE Technical Paper 2013-012687 (2013)

27. J. Baker, C. Snape, D. Scurr, 9th International Colloquium Fuels. Conventional and Future Energy for Automobiles (2013)

28. P. Lacey, S. Gail, J.M. Kientz, et al. SAE Technical Paper 2011-01-1925 (2011)

29. R. Quigley, R. Barbour, D. Arters, J. Bush, 9th International Colloquium Fuels. Conventional and Future Energy for Automobiles (2013)

30. H. Shiotani, S. Goto, SAE Technical Paper 2007-010073 (2007)

31. Z. Stępień, Nafta-Gaz 10 (2014) 